\title{
Impact of WIUT Library Activities on Labour Market Outcome
}

\author{
Abbos Utkirov ${ }^{(凶)}$ and Rauf Salahodjayev \\ Westminster International University in Tashkent, Uzbekistan \\ autkirovegmail. com
}

\section{ABSTRACT}

This paper investigates the impact of the Learning Resource Centre activities of Westminster International University Tashkent (WIUT) graduated students on the labour market outcome. WIUT library provides a learning environment that helps students to create practical teams and individual projects to support the agenda of employability. The study aims to clarify the relationship between library activities and labour market outcomes. This proposes the improvement of a commercial responsiveness workshop, in collaboration with other services, and alumni voices in an employability guide. A quantitative research approach was employed; an online survey questionnaire was distributed to alumni students to obtain the data. It was a semi-structured questionnaire designed using a Likert Scale to collect data from 607 graduates. The study revealed that LRC activities have a significant impact on labour market outcomes for students. LRC activities such as presentation skills, information technology skills, problem-solving skills, research skills were mostly expected in the labour market. Research limitations- The study was focused only on graduates of WIUT, which may limit the generalizability. Therefore, the researcher proposed to study and compare other graduates of universities in Uzbekistan. The insights are valuable for planning the curriculum of LRC activities and developing teaching practices at WIUT. Moreover, current and graduate students can learn market-oriented skills and labour market demands. This is the first-ever study in Uzbekistan that explores the relationship of university library activities on employability skills of alumni.

Keywords: alumni, employability, human resource development, labour market, library activities

Cite this article as: Utkirov, A., \& Salahodjayev, R. (2021). Impact of WIUT Library Activities on Labour Market Outcome. International Journal of Higher Education Pedagogies, 2(2), 1-25. https://doi.org/10.33422/ijhep.v2i2.26

\section{Introduction}

To endure relevancy, libraries have been acclimating their services to meet the new requirements, demand for materials, and services (Goulding, 2006; Hunt, 2017; Jerrard, 2009). For instance, public libraries have been increasing the number of curriculums and offered resources. Employability of students and skills is a key priority for the sector of Higher Education. Support for developing employability is offered by WIUT and this will be common across other institutions. The University has been developing and updating a new vision for information and digital literacy (IDL) activities. Workshops, research activities, and project collaboration at LRC WIUT can create an environment that will benefit students to adapt and become familiar with the real working environment when they approach the real-life practical workplace. More explicitly, the development of IDL workshops through a time of student at University will position them well for the level of graduate and employment and will fill them with life skills that can be transferred to the requirements of the progressively complex digital world (Mawson \& Haworth, 2018).

There's proof to appear that abilities are measured exceedingly noteworthy by graduated employers. A report by Universities UK (2016, pp. 30-31) recommends that there is coherence

(C) The Author(s). 2021 Open Access. This article is distributed under the terms of the Creative Commons Attribution 4.0 International License, which permits unrestricted use, distribution, and redistribution in any medium, provided that the original author(s) and source are credited. 
exists among graduates and managers, and esteemed aptitudes/skills and working experience are considered as a vital factor in achieving business success (Mawson and Haworth, 2018; Finch et al., 2013). Availability of a learning environment of subscribed databases, project and teamwork facilities, and IDL workshops will not only enhance achieving higher grades but also provides the atmosphere of the working process of real life. As a Brown et al., (2015, pp. 4-5) highlights, "terms such as 'entrepreneurial skills', 'problem-solving', and 'team working' might be translated in different by instruction suppliers, businesses and occupations" Exploration of problem statement could be articulated as whether there is a relationship between university library activities on employability skills of graduated students of WIUT. Therefore, identifying required current labor market skills and basing on them designing a curriculum of LRC activities can create 'skills translation' which assists how and why these soft skills can be applied. Organizing guest lectures with real successful managers, supervisors of the different organizations at the Learning resource center assists students to become more familiar with combining the theoretical approaches with real practical life experiences.

The next section reviews the extant literature of variances among workplaces and academia. This may lead to both challenges and opportunities in promoting LRC activities such as guest lectures, reading clubs, embedded sessions, information, digital literacy training, group, individual, and the team works as employability attributes. The research highlights the benefits of LRC activities and working in collaboration with students and effective services beyond the library in the employability arena.

\section{Literature Review}

There is extensive international literature on the perceptions of alumni about library activities and employability and an insignificant number in Uzbekistan. Some research has concentrated on the extent and importance of the labor market by exploring opportunities for employment in Library and Information Science (LIS). Other studies are more dedicated to the knowledge and mix of preferred skills or those required by the employers of the labor market (Genoni and Smith, 2005; Warraich and Ameen, 2010; Anne Kennan et al., 2006; Raju, 2004; Aina and Moahi, 1999; Varalakshmi, 2006; Croneis and Henderson, 2002; Stilwell, 2004; Lutwama and Kigongo-Bukenya 2004; Stephens and Hamblin, 2006; Ocholla and Shongwe, 2013).

Genoni and Smith (2005) investigated a study of LIS graduate job achievement outcomes in the prospects of Australia. This was a longitudinal study conducted by Curtin University of Technology graduates. The population of the study was alumni students who completed their studies from 1988-1992, 1993-1997, and 1998-2002. The study of 1998-2002 was compared with the outcomes of the past two studies. The outcomes indicated that many graduates searched for jobs related to the information outside libraries and the supply of employment from Curtin University is few comparing with previous years. Moreover, the use of the library was limited and international students experienced challenges due to a lack of familiarity. The findings support the need to develop library professionals' awareness of international students' use of library facilities.

Warraich and Ameen (2011) discovered a gap in the perception of alumni students about the library science curriculum's relevance to the labor market needs of Pakistan. The research was conducted with separate questionnaires for both targeted groups by using the five-point Likert scale from 1 to 5. In general, alumni students and employers were satisfied with the products of DLIS and recommended them as able to enhance the employability of new specialists through social and soft skills, etc.

Kennan et al. (2006) measured a change in employers' needs related to information professionals in Australia. The change was observed in 135 advertisements of newspapers for 
four weeks in 2004, 1994, 1984, and 1974. Their study exposed the change of job patterns. In 1974 , requests were inviting technicians or reference while in 2004, the most required attributes were behavioral characteristics and interpersonal skills.

Raju (2004) and Stilwell (2004) both piloted research from the perspective of South Africa and evaluated the awareness of employers and graduates on the appropriateness of the program to the LIS working atmosphere. Raju (2004) conducted comparative research on the curricula of LIS and the needs of employers, concluding that LIS postgrad diploma programs are reputable in South Africa. Another study carried out by Stilwell (2004) at Natal University revealed that LIS curricula achieved the predicted outcomes in postgraduates' preparation.

The research was conducted by Aina and Moahi (1999) and Lutwama and Kigongo-Bukenya (2004) on the appropriateness of East Africa School of Library and Information Science (EASLIS) from 1995 to 1999 in Uganda and Botswana University respectively. Both studies revealed that, from the employers' perspective, the graduates of EASLIS were lacking in practical skills. Aina and Moahi (1999) demonstrated the dissatisfaction of current library related jobs by respondents because of lower socioeconomic class. These skills gaps needed to be filled with Information Literacy (IL) courses.

Varalakshmi (2006) carried out comparative research on the employability of LIS alumni and the curricula of LIS at the University of Andhra in India. The survey was conducted among graduates and library professionals; it evaluated the advertisements of employees to identify the views and expectations of target groups regarding develop employment opportunities. However, LIS professionals were not satisfied with the outcomes of library institutions and believed that teaching technology, management, and soft skills to students would produce the competitiveness of employability in the future (Fajaryati et al., 2020).

Croneis and Henderson's (2002) study was from an American perspective using advertisements from College and Research Libraries News over 11 years (1990-2001). They revealed that an increasing the quantity of electronic and digital positions, and recent demand were more on supervisory and administrative in terms of job responsibilities. Their findings demonstrated the rapid change of the scale and nature of professions due to emerging technology.

Ferreira Neto et al., (2018) states that libraries should promote both physical and monetary resources to attract users and promote the programs that labor market requires. Participation of students on library programs may not help to find jobs, nevertheless it can reduce the cost which may be needed to join on the labor market. Activities are concentrated on skill training and job services. Program can help not only finding jobs but keeping the jobs for adults and positively effect on participation of labor force and impact negatively on unemployment of young generation (Hunt, 2017).

\section{Objectives of the Study}

Identification of research gaps and emerging research questions led to determine the following key objectives:

- Obtain the key competencies of LRC curriculum development

- Identify the factors of LRC activities that can benefit labor market outcomes

- Determine their Library strategies for employability successes

Moreover, WIUT library is one of the best-equipped libraries and provides a learning environment and activities which can suit the relevant labor market needed skills for students in Uzbekistan. Therefore, there is a demand to determine the employability skills of alumni students. 


\section{Research Design}

Quantitative methods were employed during the research. A descriptive quantitative research design was applied to establish an association between the variables. As part of quantitative methods, a survey questionnaire was distributed to alumni students in the online google form. The research was based on this survey questionnaire. It was a semi-structured questionnaire designed using a Likert Scale to collect data. The questionnaire was designed to gather alumni students' experiences.

\subsection{Data Collection}

The primary data was gathered in the online google form questionnaire from January to April 2020 among $(\mathrm{N}=607)$ alumni graduates (See Appendix, Figure A1). The access to alumni students' contact details was provided by the Career Centre of WIUT. The questionnaire consisted of four parts and had a combination of open and closed questions. The questionnaire incorporated questions on:

- personal information

- opinions about the curriculum learning while studying at WIUT

- perception of employability skills

- use of the library

The questionnaire's common indicator data sets were adopted from Warraich (2008). Moreover, secondary data were obtained from databases, journal articles, and books. In order to determine the participation in LRC activities, the 1024 WIUT alumni graduates were given the online questionnaire and 607 of them responded (See Appendix, Figure A1). Quantitative data analysis was used to discover the differences in employability and position between high attended alumni compared to low attended alumni student's on LRC activities and workshops.

\section{The Data Analysis and Interpretation}

\subsection{Profile of Respondents}

Malhotra (2010) highlights that the core objective of the process of data analysis is to obtain valuable insights through research questions. Online google form survey (See Appendix, Figure A1) was sent to graduate students via e-mail, cell phone (messaging), telegram (messenger), Facebook, and LinkedIn. 110 (18\%) graduates responded to the questionnaire via e-mail, 72 (12\%) via Facebook, 37 (6\%) via LinkedIn, 74 (12\%) via cell phones and messaging, and 314 via Telegram (WIUT Alumni Network, 2020). Software for Statistics and Data Science (Stata) and the Tableau data visualization analysis tool were used to analyze and manage the quantitative data. Graduates who were on maternity leave and continued their masters studying were about 63 respondents and they were excluded to eliminate the subjectivity of library activities' impact on employability.

The demographic profile is described next. 607 students out of 1024 participated in this survey. The response rate was nearly $60 \% .391$ (64.3\%) respondents were male and $217(35.7 \%)$ were female $371(61 \%)$ of the respondents were working in private sectors while $173(29.7 \%)$ were in public sectors. $63(10 \%)$ alumni were on maternity leave or continuing their studies. 504 $(83 \%)$ of the respondents were aged between $21-30$. The remaining $103(17 \%)$ of the respondents were over the age of 30 (31-42).

The salary of 239 (39\%) graduates was above 6000000 Uzbek so'm, while 305 (50\%) was from less than 2000000 to 6000000 Uzbek so'm per month. 63 (105) of the whole $(\mathrm{N}=607)$ respondents were on maternity leave and studying. It should be noted that the $471(77 \%)$ 
students who frequently visited libraries (from once in a day or month) have a salary of over 5 million so'm compared to the $73(12 \%)$ students who visited rarely and never $(\mathrm{N}=544)$, excluding maternity leave and studying students (63 respondents).

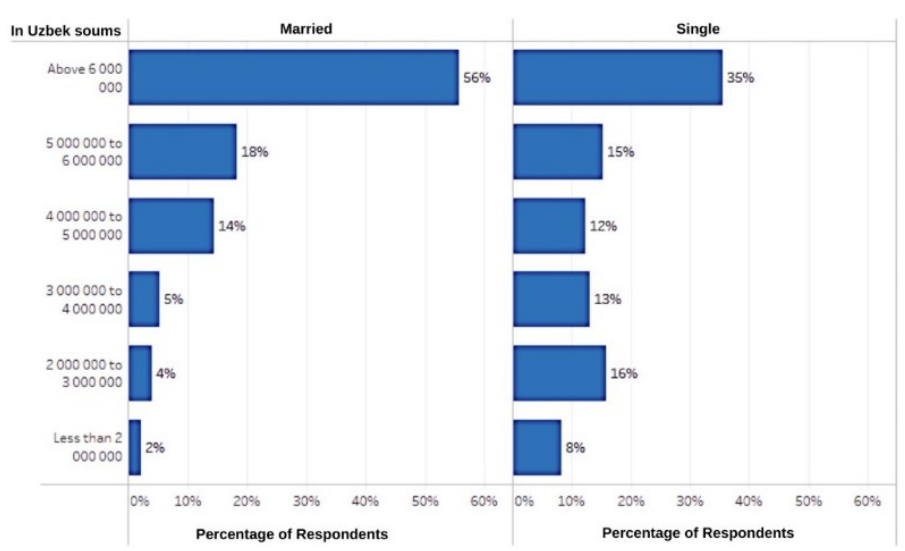

Figure 1: Average monthly salary breakdown by marital status (in Uzbek soums)

Figure 1 demonstrates that married graduates earn more, from $4 \mathrm{mln}$ (Uzbek so' $\mathrm{m}$ ) to above 6 $\mathrm{mln}$ (Uzbek so' $\mathrm{m}$ ), while the single professionals' proportion is among less than $2 \mathrm{mln}$ (Uzbek so' $\mathrm{m}$ ) to $3 \mathrm{mln}$ (Uzbek so' $\mathrm{m}$ ). This means that married people are more responsible and keen on earning more money. Another point is that married people can be more experienced and have the opportunity to find high salary jobs (Figure 7).

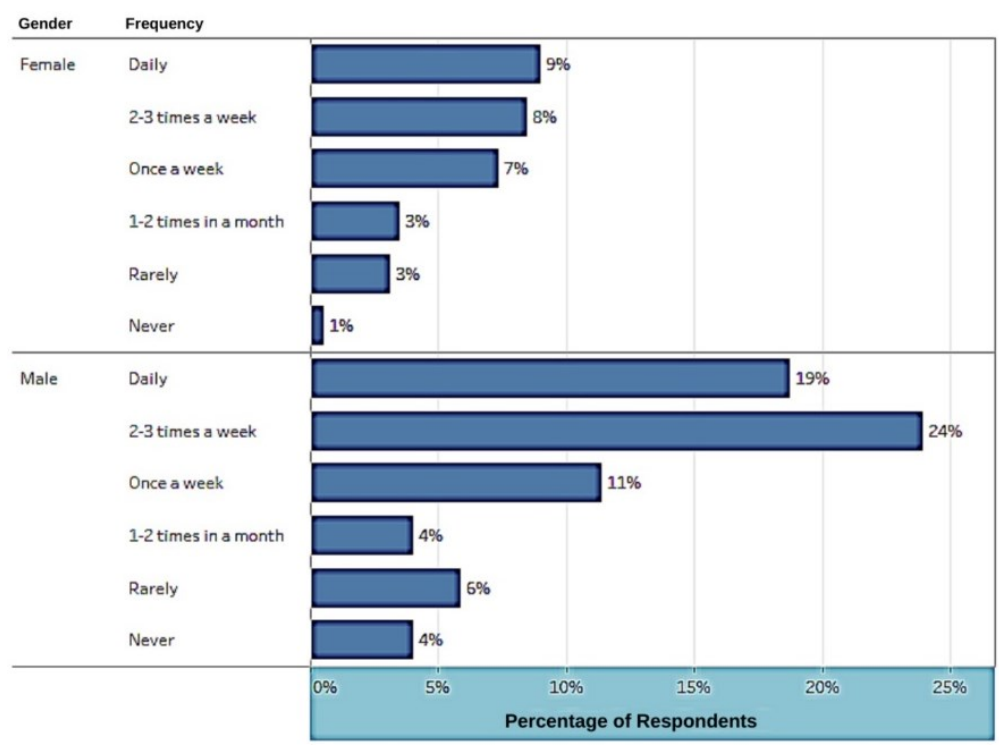

Figure 2: Frequency of library visits by gender (Out of 607)

As Figure 2 shows, male students were visited more compared to female respondents. The highest percentage ratio of 9 percent of daily visits on the female while 24 percent male visits observed on 2-3 times a week. This means that male students were more dedicated to participating in LRC activities compared to females.

Most of the respondents $(300,62 \%)$ got their first job within one month of graduation - 271 of these respondents $(90.3 \%$ out of 300$)$ were students who frequently visited libraries. $196(37 \%)$ respondents got their first job within 4-6 months. The remaining 6\% got their job in the range of 7 to 24 months (Figure 3). It should be noted that 63 respondents' answers were maternity and studying reasons and 19 of respondents' answers were blank or error. Their responses were therefore excluded to provide an accurate analysis. As stated above, 62 percent of students who 
frequently visited libraries got their job during the first month. This demonstrates the good labor market for WIUT graduates in Uzbekistan.

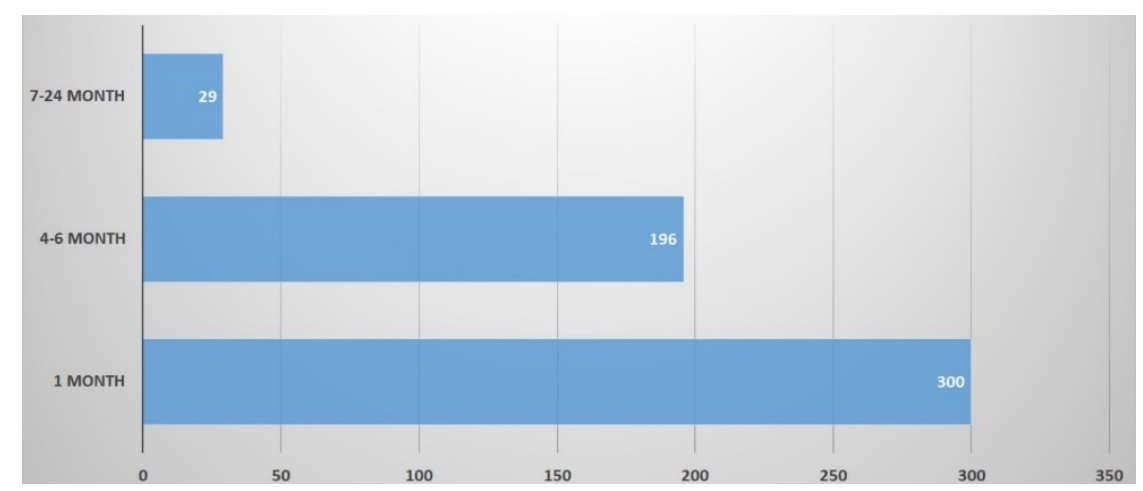

Figure 3: Unemployment period after graduation (Out of 525)

\subsection{Correlation and Regression Analysis}

In order to discover the intensity of the relationship between the variables, following the correlation matrix can help to illustrate an accurate outcome.

\section{Correlation Matrix}

According to the results from this correlation matrix, in the line of library visits, it can be observed that the highest absolute correlation exists between income (salary) of respondents and frequency of library visits with a nearly moderate positive relationship $(\mathrm{r}=.4)$. As research questions 1 and 2 are about identifying the positive effects of LRC activities on students' employability, it is useful to note the statistically significant correlation (90\% confidence) between income and how frequently the students visited the library. Additionally, a negative correlation was observed between library visits and gender $(\mathrm{r}=-.01)$ and library visits and employee category $(\mathrm{r}=-0.10)$

Table 1.

Correlation Matrix

\begin{tabular}{|c|c|c|c|c|c|c|c|c|}
\hline & $\begin{array}{l}\text { Library } \\
\text { Visits }\end{array}$ & $\begin{array}{l}\text { Income } \\
\text { (salary) }\end{array}$ & Age & Gender & $\begin{array}{l}\text { Working } \\
\text { Sector }\end{array}$ & Marriage & $\begin{array}{l}\text { Employee } \\
\text { category }\end{array}$ & Faculty \\
\hline $\begin{array}{l}\text { Library } \\
\text { Visits }\end{array}$ & 1.00 & & & & & & & \\
\hline $\begin{array}{l}\text { Income } \\
\text { (salary) }\end{array}$ & $0.40^{*}$ & 1.0000 & & & & & & \\
\hline Age & $0.13 *$ & $0.37^{*}$ & 1.00 & & & & & \\
\hline Gender & -0.01 & $-0.21 *$ & $-0.12 *$ & 1.00 & & & & \\
\hline $\begin{array}{l}\text { Working } \\
\text { Sector }\end{array}$ & $0.13 *$ & 0.02 & 0.021 & 0.02 & 1.00 & & & \\
\hline Marriage & $0.13 *$ & $0.28 *$ & $0.54 *$ & -0.06 & 0.05 & 1.00 & & \\
\hline $\begin{array}{l}\text { Employee } \\
\text { category }\end{array}$ & $-0.10 *$ & $-0.24 *$ & -0.07 & $0.12 *$ & -0.02 & -0.06 & 1.00 & \\
\hline Faculty & 0.02 & 0.03 & 0.07 & 0.01 & $0.14 *$ & -0.04 & -0.05 & 1.00 \\
\hline
\end{tabular}

A strong correlation can be observed (income line) between age and income, meaning a person earns more money as he or she becomes older, which is statistically significant $(\mathrm{r}=.37)$. There is a relatively positive correlation between income and faculty $(\mathrm{r}=.03)$ and income and working sector $(\mathrm{r}=.02)$, but they are not statistically significant. We can observe the highest statistically significant correlation in this table between age and marriage $(\mathrm{r}=.54)$, which means more older people are married compared to young people. For gender, the highest score of a statistically significant relationship can be observed between gender and employee category $(r=.12)$. For 
the working sector, the highest is only between the working sector and faculty $(\mathrm{r}=.04)$. The faculty and employee category has a relatively negative correlation $(\mathrm{r}=.05)$ which means it does not matter which category of employment suits the student (part-time, permanent, or other) as the degree type (business, economics, IT, etc.) does not affect.

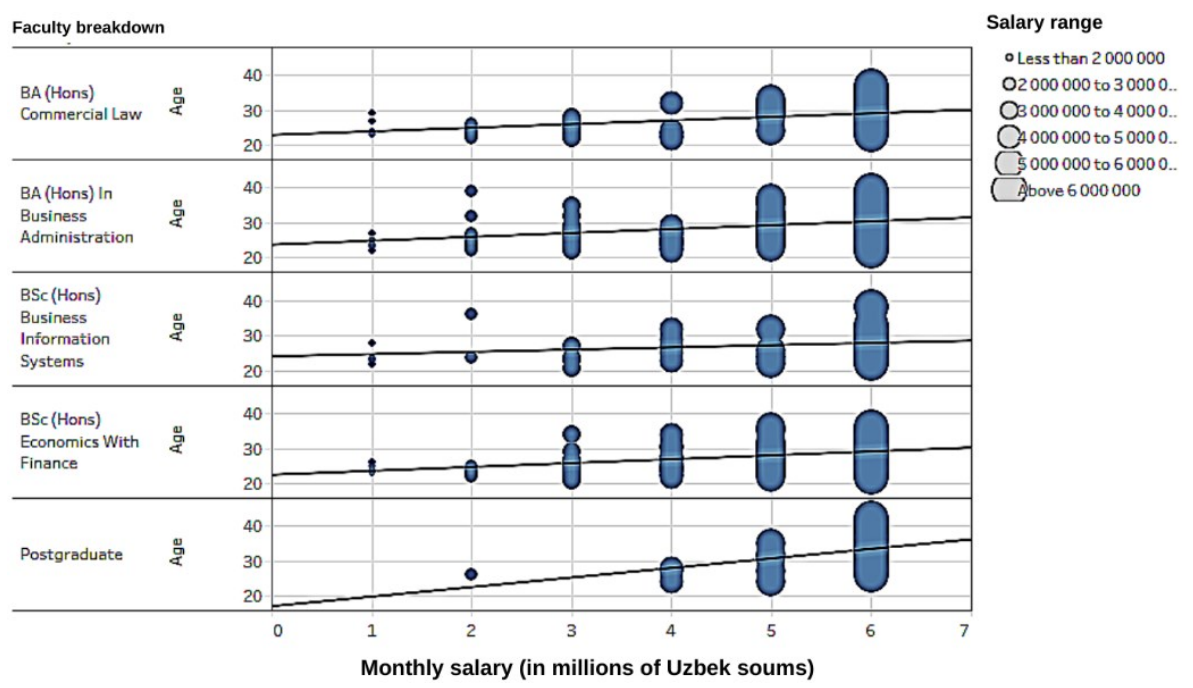

Figure 4: Scatterplot by age and income broken down by faculty

A scatterplot can show us a more detailed visual. As we see only Postgraduate students of WIUT have a visible increase in the scale of income as the graduates become older and also show positive statistically significant correlation in all aspects (Figure 4).

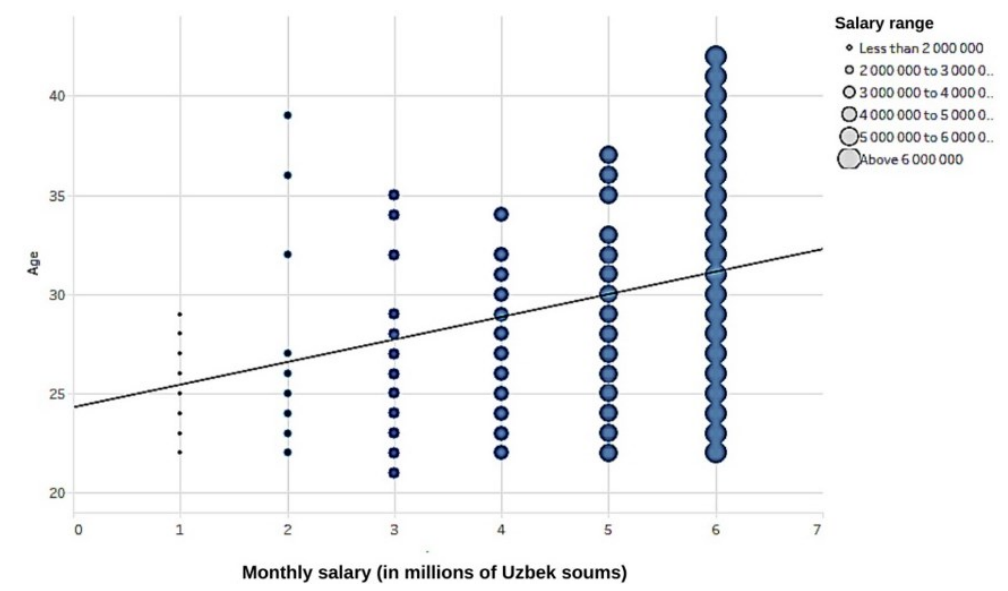

Figure 5: Correlation Matrix of income (salary) and age

Figure 5 shows that as a person becomes older, they earn more money. This means they can become more experienced and competent, providing further opportunities for earning a greater income. 


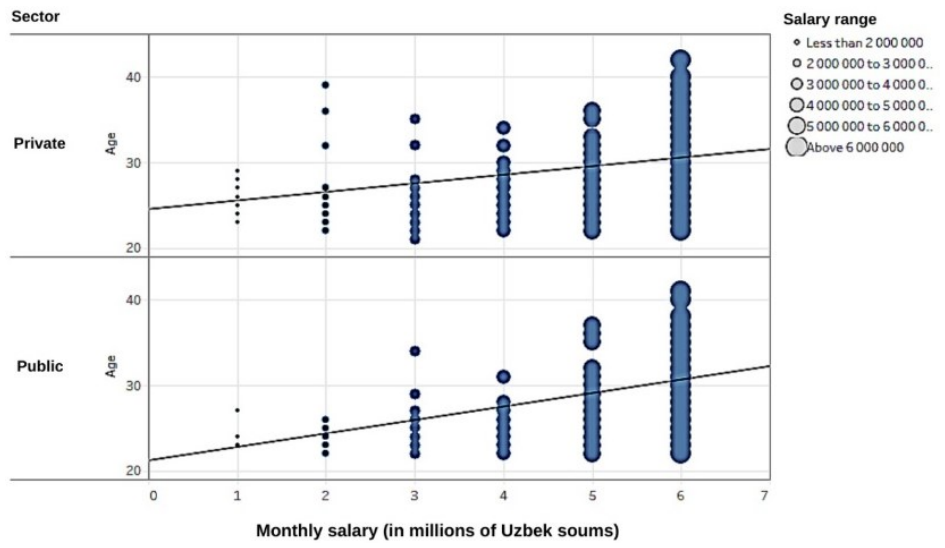

Figure 6: Scatterplot of by age and income (salary) broken down by sectors

If breakdown into two sectors as Figure 6 illustrates that graduates who started to work in public sectors are younger in age and the faster the increase in income comparing to private sector employees. Moreover, from Figure 7 we can observe that married people earn more compared to single people.

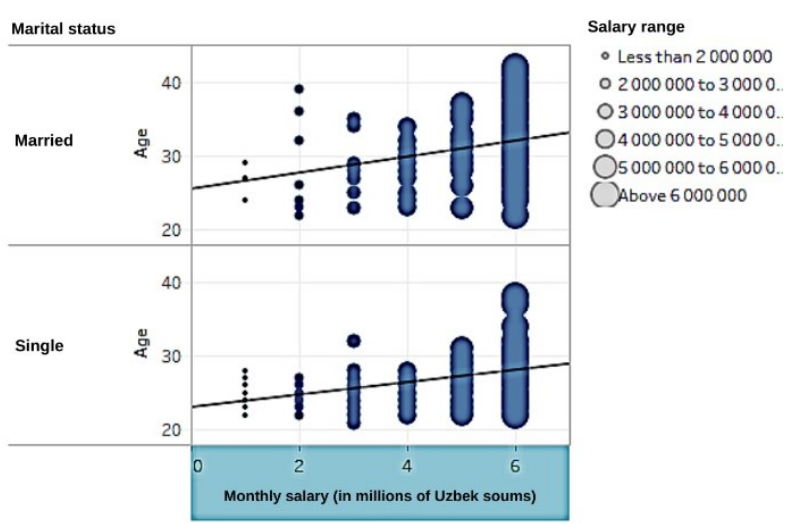

Figure 7: Scatterplot of by age and income (salary) broken down by marital status

\section{Regression Analysis}

As we can see in the summary of regression output, several points can be noted in Table 2 . The number of observations is 544 . It should be noted that 63 respondents $(607-63=544)$ were excluded because of maternity and studying reasons to provide accurate calculations. F-Test shows that the p-value is .000 which means the results are highly significant; the significance level is $95-99 \%$ percent respectively. R-square $(0.1633)$ is not equal to zero which means the regression model has some explanatory power. R-squared is a statistical measure of how close the data are to the fitted regression line. As the R-Square value is between 0 and 1 and it is the coefficient of determination. As closer to 1 is better as close to 0 means the worst the model. As Table 2 shows, 16.33 percent of variation shows a weaker relationship even that is statistically significant of library visits of student's effect on the income of respondents. However, the other 16 percent is either unexplained or an error in this model. Following from R-Squared, T-value can also be interpreted as less than 0.1 ; we can see that both coefficients in library visits are right, essentially the coefficient for library visits rate is equal to zero and the constant is also equal to zero. It means that frequent library visits have a significant effect on the income of students after graduation. The coefficient for library visits is .46 and 2.50 for the constant. This essentially shows the nature of the relationships between variables. When income is zero the library visits are 2.50 . As we see, .46 is a positive number which means frequent library visits have a positive relationship with the income of WIUT alumni students. 
Owing to this fact, it observes that one more students visit the library caused a 0.5 increase in income of students after graduation from university (Table 2).

Table 2.

Regression analysis income (wage) to frequent visits to the library

\begin{tabular}{|c|c|c|c|c|c|c|}
\hline \multicolumn{3}{|c|}{ ANOVA (Analysis of variance) } & \multicolumn{4}{|c|}{ Regression statistics } \\
\hline Source & SS & df & MS & & $\begin{array}{r}\text { Number of obs }= \\
F(1,542)=\end{array}$ & $\begin{array}{l}544 \\
105.76\end{array}$ \\
\hline \multirow[t]{4}{*}{ Model } & 235.775442 & 1 & 235.775442 & & Prob $>F=$ & 0.0000 \\
\hline & 1208.34221 & 542 & 2.22941366 & & R-squared $=$ & 0.1633 \\
\hline & 1444.11765 & 543 & 2.65951685 & & Adj R-squared = & 0.1617 \\
\hline & & & & & Root MSE $=$ & 1.4931 \\
\hline \multicolumn{7}{|c|}{ Coefficients } \\
\hline Income & Coef. & Std. Err. & $\mathrm{t}$ & $\mathrm{P}>\mathrm{t}$ & {$[95 \%$ Conf. } & Interval] \\
\hline $\begin{array}{l}\text { Library } \\
\text { visits }\end{array}$ & .460076 & .0447379 & 10.28 & 0.000 & .3721951 & .547957 \\
\hline cons & 2.495247 & .2106269 & 11.85 & 0.000 & 2.081502 & 2.908992 \\
\hline
\end{tabular}

We can conclude that library activities have a significant impact on students' labor market outcomes.

Opinions About the Curriculum of LRC

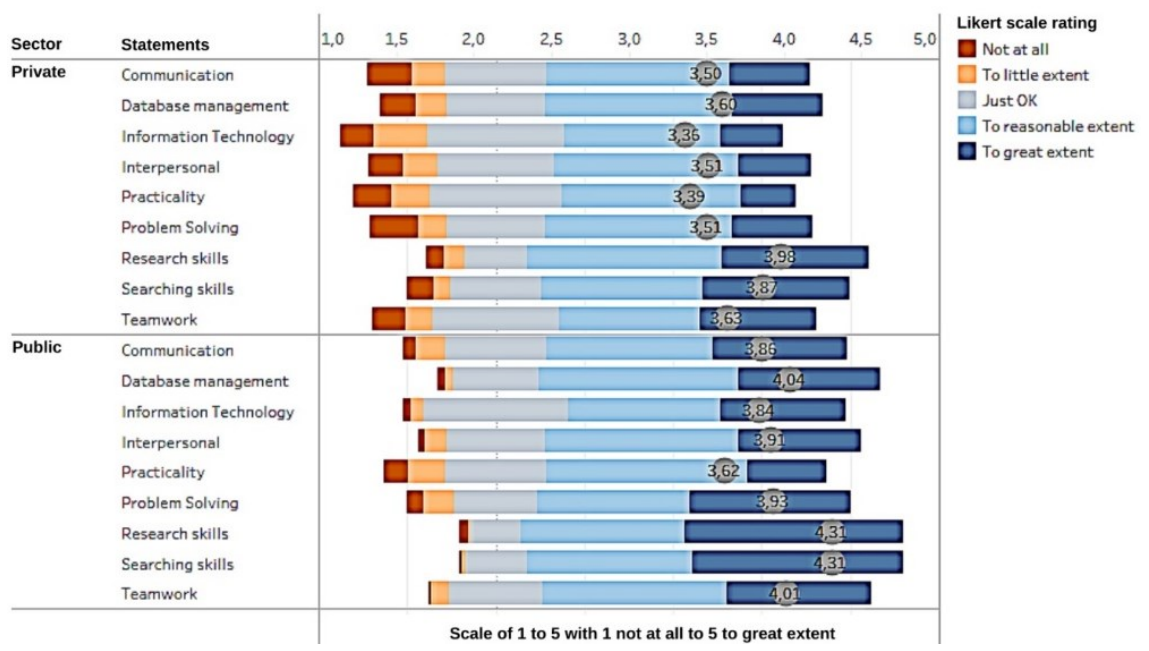

Figure 8: Graduates opinion about library activities at WIUT: Average score between private and public sector

Note: 1- Not at all 2-To a little extent 3-Just OK 4-To reasonable extent 5-To great extent

To see the significant difference between means of opinions, the Likert scale (Tableau data visualization analysis tool) has been used to measure (from 1 to 5) the most frequent responses which is the mode and average score by working sector (Figure 8). As we can see in all aspects, alumni students who work in the public sector provided the opinion that WIUT Learning Resource Center (library) activities (training sessions, reading club, conferences, and events) play an effective role in developing the skills in all aspects compared to private sector employees. The highest scores in the private sector are research (Avg.Score=3.98) and searching skills (Avg.Score=3.87), while public sector research (Avg.Score=4.31) and searching skills (Avg.Score=4.31) are leading with a higher score. The lowest score has different skills development as the private sector has information technology (Avg.Score=3.36) 
while in the public sector has practicality (Avg.Score=3.62) (Activities contents are related to Practical approach). It can be assumed that library activities' impact is lower in IT skills for the private sector, whereas practicality's impact is lower in public sectors. As WIUT has concentrated on a blended learning approach, library activities should develop IT and practical approaches in designing its curriculum.

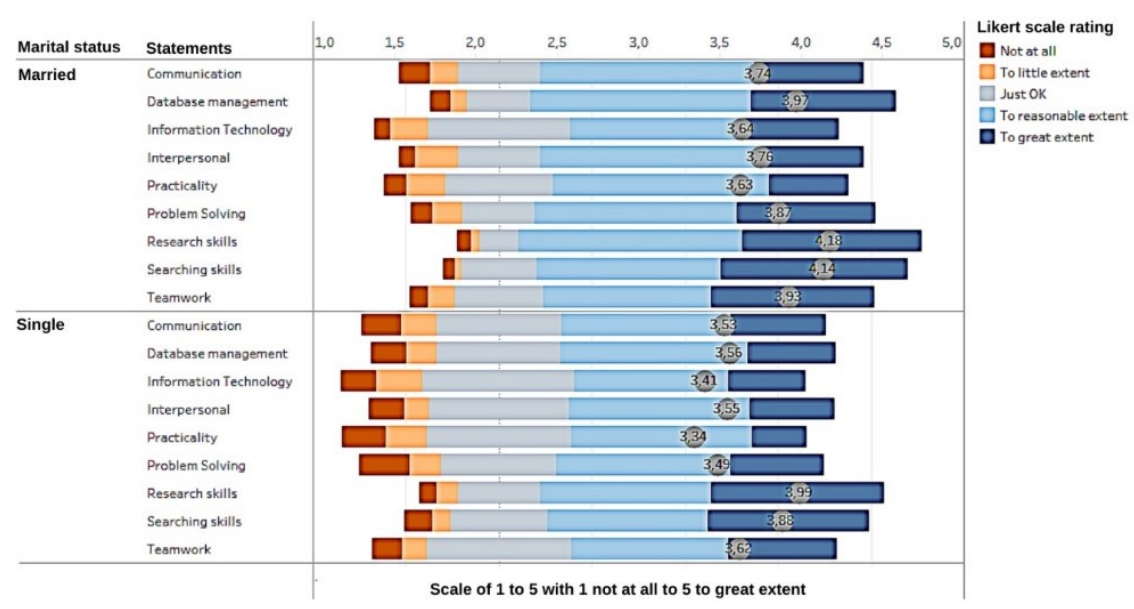

Figure 9: Graduates opinion about library activities at WIUT: Average score between married and single

Note: 1- Not at all 2-To a little extent 3-Just OK 4-To reasonable extent 5-To great extent

Similar outcomes can be observed in that research skills are leading in both married (Avg.Score $=4.18)$ and single (Avg.Score=3.99) respondents. The close lowest score with practicality in married (Avg.Score=3.63) and single (Avg.Score=3.34). It means that the average score of the married and the single has no significant difference in all aspects.

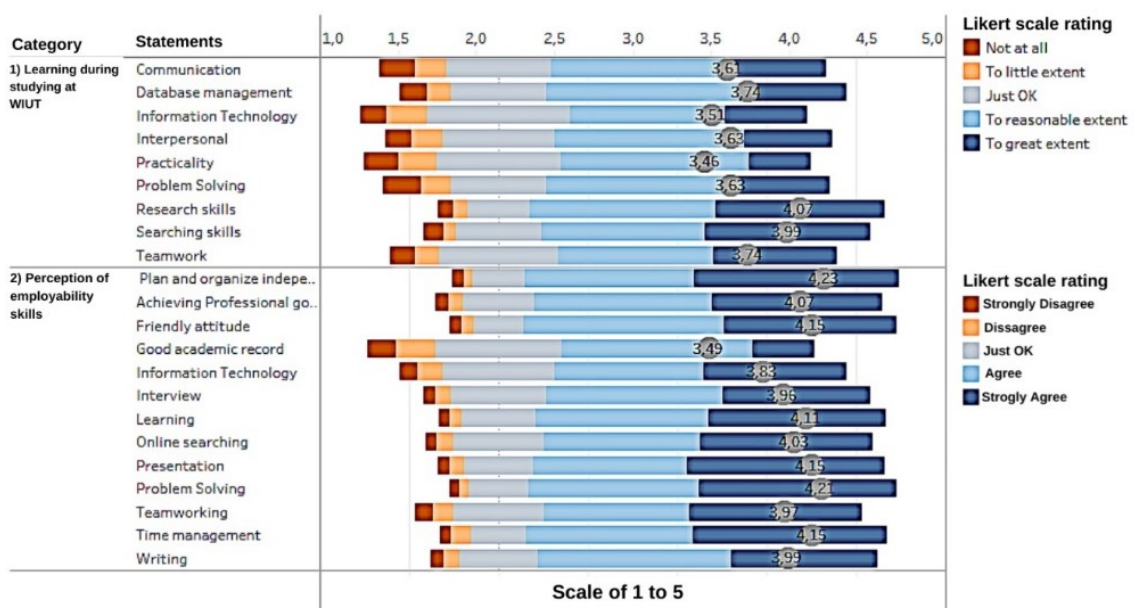

Figure 10: Average score between learning activities and perception of employability skills

Notes: Category 1: 1- Not at all 2-To a little extent 3-Just OK 4-To reasonable extent 5-To great extent Category 2: 1- Strongly Disagree 2- Disagree 3-Just OK 4-Agree 5- Strongly Agree

Comparing two categories. it can be observed that learning activities have lower scores in all aspects compared to employability skills. This means students perceived the majority of soft skills during their studies at WIUT not very important until they approached real employment procedures. Therefore, the importance of employability skills should be developed with a more practical approach in designing the curriculum of LRC activities. These outcomes and analysis from alumni students can help to produce more practical and current skills development for 
students to develop and maintain further employability opportunities. This suits the third research question this study is intended of attracting beneficial LRC activities to students and designing more developed curricula in upcoming academic years.

Table 3.

Average wage rate of WIUT students

\begin{tabular}{llllll}
\hline Sum of income & & & & & \\
\hline Variable & Obs & Mean & Std. Dev. & Min & Max \\
Salary (income) & 544 & 4.558824 & 1.630803 & 1 & 6 \\
\hline
\end{tabular}

Table 3 shows useful information; the average salary wage is about 4.6 million Uzbek soum for 544 respondents.

\section{Use of Library}

Both the academic and administrative staff of WIUT university must become aware of the reasons for students coming to the university and the library. From Figure 15 we can determine that students visit LRC to complete assignments (85\%), prepare for exams $(76 \%)$, research $(55 \%)$, borrow books $(38 \%)$, reference $(37 \%)$, and others. The results prove that the majority of students come to the library to study to become successful in their careers and lives.

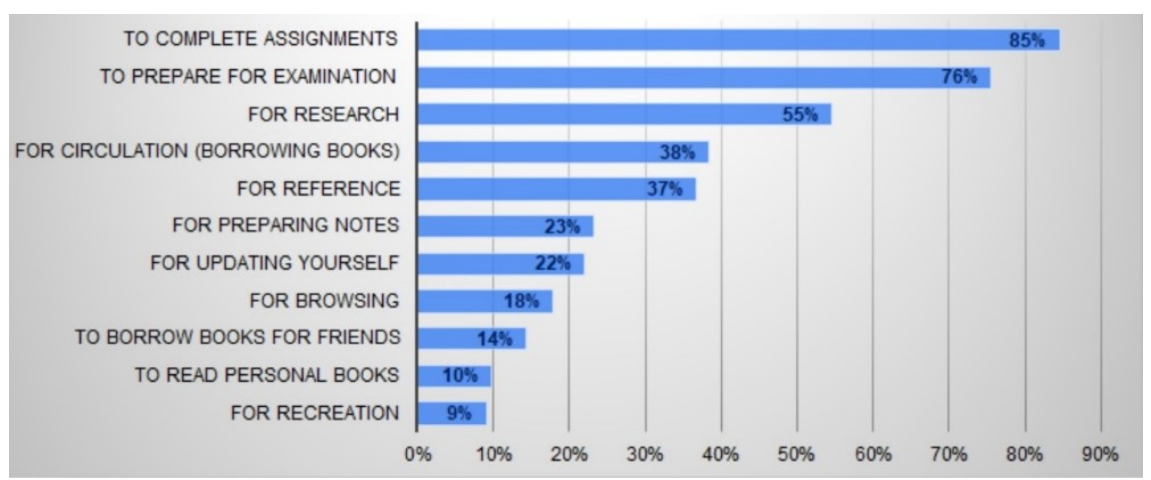

Figure 11: Purpose of students' visiting WIUT library during studies (Out of 607)

As we see students mainly use circulation services (57\%) and book a reservation (48\%), which means that students mainly use the library for the check-in and check-out of resources. However, the usage of referencing (42\%) and digital library (32\%) services demonstrates that the library is moving to a blended learning mode. However, there are a lot of essential services of WIUT LRC, such as referencing tool session (11\%), which teaches database usage and proper referencing. Nonetheless, not many students are aware of or do not intend to learn this, which is much needed in completing assignments and for research purposes. Moreover, the WEBOPAC service (8\%) provides a service to manage reserved and borrowed books online at home. Therefore, these needed tools should be considered for further development by WIUT LRC services. 


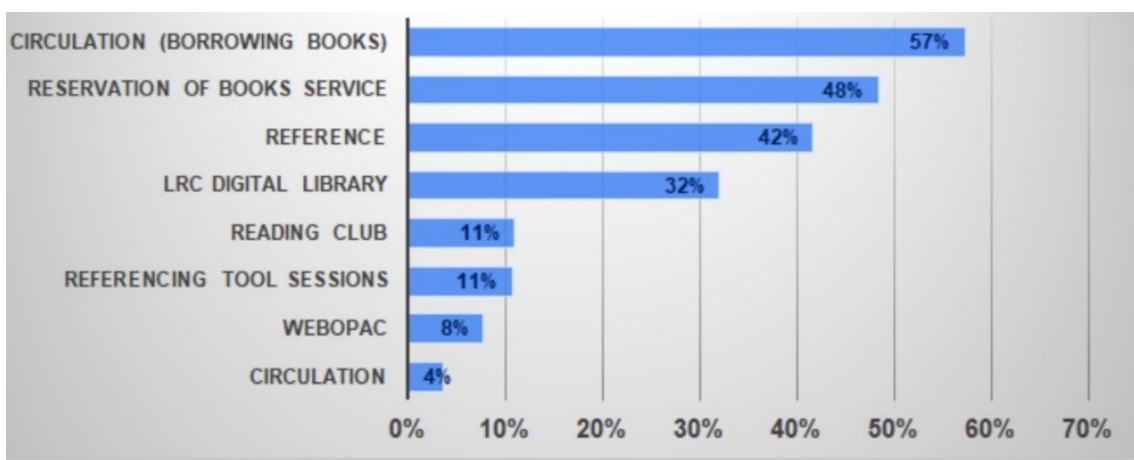

Figure 12: Usage of WIUT library services during studies (Out of 607)

\section{Summary and Recommendations}

As we see the real outcomes showed that there was a significant effect of LRC activities on employability at all. It was interesting to see the difference between research outcomes in a different perception of graduate students from different perspectives and background, culture, and others. Frequent library visits have a positive relationship with the income of WIUT alumni students. However, students need to improve presentation skills, IT skills, problem-solving, research skills which are vital to enrich employability in the labor market. Since students are not aware of the labor market needs until they approach the real workplace. Considering these, the library specialists should work in collaboration with academic staff and practitioners to implement market-driven skills into curricula and transfer them to current students. Collaboration between academic and library staff can be related to choosing appropriate learning resources and enclosing information literacy skills in curricula. Such collaboration maintains the relevance of information instruction to particular disciplines and increases the students' perceived value (Pham \& Tanner, 2015). Thus, the learners will be aware of the current labor market needs and improve their competencies. Moreover, enhancing internship opportunities and practical opportunities can help to be aware of the real essential skills that potential employers required. It should be noted that the study is limited to those who studied at WIUT. Comparing the research with other library activities of universities in Uzbekistan will help to create applicable curricula for activities that can provide valuable insights for future graduates' employability. Furthermore, the employment status and salary of graduates who are continuing their studies can not be measured because they may not work or work as part-time employers. Also, not every graduate of WIUT was reached to be answered for the questionnaire. Some of the alumni preferred not to fill the questionnaire because the salaryrelated question seemed confidential information for them even it is anonymous.

Based on survey results LRC professionals should design the curriculum materials in the areas of IT skills, presentation skills, problem-solving skills, and research skills. Training of faculty librarians on the web searching, design of databases, referencing tools should also be part of the program. The designed courses should be revised with a flexible approach every two or three years considering employability market changes. Conducting longitudinal research can provide the opportunity of evaluating students and labor market needs. Working with the Career Center of the university can help to build and maintain networking among universities and employers.

\section{Conclusion}

Although this project is intended for a deep analysis of the impact of WIUT LRC activities on labor market outcome, limitations, and recommendations were observed and listed above. Analysis of current research provided valuable information for WIUT university and the library to measure the impact of LRC activities in the employability arena. The world is changing 
quickly and theoretical knowledge is becoming not enough to survive in the competitive market. Activities should be concentrated on market-oriented skills to resolve the challenging employer needs. Providing market-driven skills on LRC activities such as presentation skills, IT skills, problem-solving, research skills with high intensive motivation and commitment. Furthermore, developing an innovative method for a program to enhance soft skills for library staff can provide professional experts that can encourage labor market needed skills development for students' career and life success (Junrat et al., 2014). Implementing features that can strengthen the skills of the current job market and curriculum of LRC activities should mirror to produce talented professionals for the information marketplace.

\section{Acknowledgments}

We would like to thank and grateful to Dr. Viktoriya Levinskaya, WIUT LRC Enhancement Unit, and WIUT Research department for their support in conducting questionnaires and the structure of this paper. Special thanks to WIUT Career Centre and Alumni Unit for providing access to alumni students.

\section{References}

Aina, L, and Moahi, K. (1999). Tracer study of the Botswana library school graduates Semantic Scholar. https://doi.org/10.3233/EFI-1999-17304

Aina, L. O., \& Moahi, K. (1999). Tracer study of the Botswana library school graduates. Education for Information, 17(3), 215-244. https://doi.org/10.3233/EFI-1999-17304

Brown, A. N., Rankin, K., Picon, M., \& Cameron, D. B. (2015). The state of evidence on the impact of transferable skills programming on youth in low-and middle-income countries. https://www.3ieimpact.org/sites/default/files/2019-01/sp4-youth_and_transferable_skills.pdf

Croneis, K. S., \& Henderson, P. (2002). Electronic and digital librarian positions: A content analysis of announcements from 1990 through 2000. Journal of Academic Librarianship, 28(4), 232-237. https://doi.org/10.1016/S0099-1333(02)00287-2

Fajaryati, N., Budiyono, B., Akhyar, M., \& Wiranto, W. (2020). The employability skills needed to face the demands of work in the future: Systematic literature reviews. Open Engineering, 10(1), 595-603. https://doi.org/10.1515/eng-2020-0072

Ferreira Neto, B., Market Paper Amir Borges Ferreira Neto, J., Boudreaux, C., Conaway, B., Deskins, J., Freguglia, R., Grossman, D., Fernandes, I., Humphreys, B., Jackson, R., Lin, J., Matti, J., Marioni, L., Minuci, E., Nowak, A., Pyun, H., Ross, A., Ross, J., Sayago, J., ... Zhou, Y. (2018). Do public libraries impact local labor markets? Evidence from Appalachia Do Public Libraries Impact Local Labor Markets? Evidence from Appalachia I would like to thank Izabella. https://mpra.ub.uni-muenchen.de/89584/1/MPRA_paper_89584.pdf

Finch, D. J., Hamilton, L. K., Baldwin, R., \& Zehner, M. (2013). An exploratory study of factors affecting undergraduate employability. Education And Training, 55(7). https://doi.org/10.1108/ET-07-2012-0077

Genoni, P., \& Smith, K. (2005). Graduate employment outcomes for qualifying library and records management courses at curtin university of technology, 1998-2002. Australian Library Journal, 54(4), 336-352. https://doi.org/10.1080/00049670.2005.10721782

Goulding Anne. (2006). Public Libraries in the 21st Century. E-Conversion - Proposal for a Cluster of Excellence; Routledge. https://doi.org/10.4324/9781315602912

Hunt, K. (2017). Library Programs and Services for New Adults. Libraries Unlimited. https://books.google.co.uz/books?id=YE83DwAAQBAJ\&pg=PA92\&lpg=PA92\&dq=Library 
+ Programs + and + Services + for + New + Adults + Kyla + Hunt + pdf\&source $=$ bl\&ots $=$ sQGuoaKvm\&sig=ACfU3U07N3B6ZUJjDm6tRhkzKZKi0VuwXw\&hl=ru\&sa=X\&ved=2ahUKEwiG1 8Wu5-DtAhUii8MKHRmzCr84ChDoATAEegQIBRA

Jerrard, J. (2009). Crisis in Employment: A Librarian's Guide to Helping Job Seekers. American Library Association. https://books.google.co.uz/books?id=AePSfMFsVTMC\&pg=PA44\&lpg= PA44\&dq $=$ Jerrard, $+\mathrm{J} .+$ Crisis + in + employment $+\mathrm{a}+$ librarian $\% 27 \mathrm{~s}+$ guide + to + helping + job + seeker s. + American + Library + Association\&source $=$ bl\&ots $=3 \mathrm{NdZwSt7Br \& sig}=$ ACfU3U3Y8fGRCVQ XDEZfDDzmQZnNFeOVjw\&hl=ru\&sa $=$ X\&ved

Junrat, S., Jenphop, C., Suravee, R., \& Kanokorn, S. (2014). Soft Skills for University Library Staff in Thailand. Procedia - Social and Behavioral Sciences, 112, 1027-1032. https://doi.org/10.1016/j.sbspro.2014.01.1265

Kennan, M. A., Cole, F., Willard, P., Wilson, C., \& Marion, L. (2006). Changing workplace demands: What job ads tell us. In Aslib Proceedings: New Information Perspectives (Vol. 58, Issue 3, pp. 179-196). Emerald Group Publishing Limited. https://doi.org/10.1108/ 00012530610677228

Lutwama, E. and Kigongo-Bukenya, I. M. N. (2004). A tracer study of the East African School of Libraryand Information Science graduates 1995-1999 working in Uganda | Lutwama | South African Journal of Libraries and Information Science. https://doi.org/https://doi.org/ $10.7553 / 70-2-675$

Malhotra, N. (2010). Marketing Research: An Applied Orientation (S. Yagan (ed.); 6th ed.). Prentice Hall. http://www.ru.ac.bd/wp-content/uploads/sites/25/2019/03/407_08_00_ Malhotra-Marketing-Research-An-Applied-Orientation.pdf

Mawson, M., \& Haworth, A. C. (2018). Supporting the employability agenda in university libraries. Information and Learning Science, 119 (1/2). https://doi.org/10.1108/ILS-042017-0027

Ocholla, D., \& Shongwe, M. (2013). An analysis of the library and information science (LIS) job market in South Africa. South African Journal of Libraries and Information Science, 79(1). https://doi.org/10.7553/79-1-113

Pham, H. T., \& Tanner, K. (2015). Collaboration Between Academics and Library Staff: A Structurationist Perspective. Australian Academic and Research Libraries, 46(1), 2-18. https://doi.org/10.1080/00048623.2014.989661

Raju, J. (2004a). First level i library and/or information science education and training at South African universities and technikons: developments in specialisation. https://doi.org/ 10.7553/70-1-689

Raju, J. (2004b). First level library and/or information science qualifications at South African universities and technikons: a comparative study of curricula. South African Journal of Libraries and Information Science, 70(1). https://doi.org/10.7553/70-1-689

Stephens, D., \& Hamblin, Y. (2006). Employability skills: Are UK LIM departments meeting employment needs? The results of a survey of employment agencies identifies gaps in UK LIM curricula in the UK. New Library World, 107(5-6), 218-227. https://doi.org/10.1108 /03074800610665211

Stilwell, C. (2004). Alumni perceptions of a post graduate Information and LibraryScience Education programme at the University of Natal, South Africa. South African Journal of Libraries and Information Science, 70(1). https://doi.org/10.7553/70-1-691 
Universities UK. (2016). Higher education in England: provision, skills and graduates. https://dera.ioe.ac.uk/27441/1/higher-education-in-england-provision-skills-and-graduates.pdf

Varalakshmi, R. S. R. (2006). Educating 21st Century LIS Professionals-Needs and Expectations: A Survey of Indian LIS Professionals and Alumni. Journal of Education for Library and Information Science, 47(3), 181. https://doi.org/10.2307/40323829

Warraich, N., \& Ameen, K. (2011). Alumni Perception of Library and Information Science Programme and Graduate Employment Outcomes at the University of the Punjab. November.

Warraich, N. F. (2008). LIS Graduates Employability-Needs and Expectations of the Library and Information Science (LIS) curriculum at the University of the Punjab (PU): An appraisal of Pakistani LIS Professionals Date : 02/07/2008. Education And Training, 2007, 1-20.

Warraich, N. F., \& Ameen, K. (2010). Employment and learning outcomes of LIS graduates: A case of Pakistan. Education for Information, 28 (2-4), 315-324. https://doi.org/10.3233/ EFI-2010-0914 


\section{Appendix}

Figure A1: Alumni Questionnaire

\section{Alumni Questionnaire (Adapted from: Warraich, 2008)}

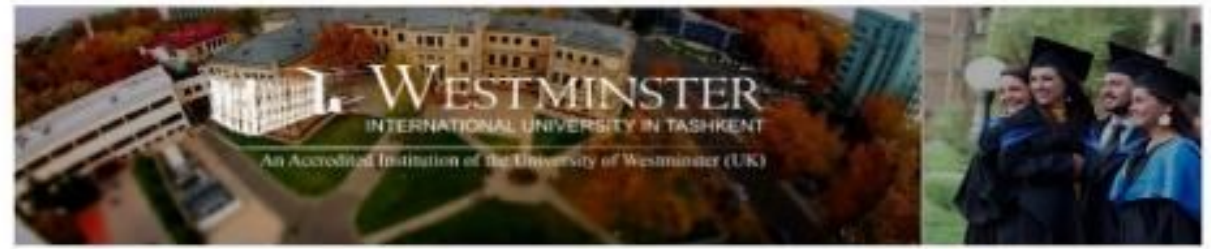

My name is Abbos Utkirov, a postgraduate student of MA IBM at WIUT. I am collecting data for my research paper "Impact of WIUT Library activities on labor market outcome". The aim of the survey is to measure the employability and problems of WIUT graduates. Please read all the questions carefully. The survey has been designed to facilitate easy answering. The answer requires either a select option or to indicate your appropriate responses. There are no right or wrong answers. We want to know your personal opinion. Please answer sincerely to help with the success of our investigation.

Your responses will be kept in secret.

* Required

\section{Gender *}

Mark only one oval.
Male
Female
Other:

\section{Age *}




\section{Faculty *}

Mark only one oval.

BA (Hons) In Business Administration

BSc (Hons) Economics With Finance

BA (Hons) Commercial Law

BSc (Hons) Business Information Systems

Other:

\section{Category of Employee *}

Mark only one oval.

Permanent employee

Part time employee

$\square$ Unemployed

Studying

Maternity live (child care)

Other:

5. Marital status *

Mark only one oval.

Married

Single

Other:

6. Current Job position or study (please add also the name of your company/organization) * 
7. How long you remained unemployed after completing WIUT months? (if you are continuing your study write it here) *

8. What sector do you work in?*

Mark only one oval.

Public

Private

Other:

9. How many employee/professionals are working in your organization? ${ }^{*}$

Mark only one oval.
$1-100$
$100-200$
200-300
$300-400$
$400-500$
500-600
Above 600 
10. Your monthly Income level (in Uzbek sums) *

Mark only one oval.

$\bigcirc$ Less than 2000000

2000000 to 3000000

3000000 to 4000000

4000000 to 5000000

5000000 to 6000000

Above 6000000

11. As an employed WIUT graduate, give your opinion to what extent WIUT Learning Resource Center (library) activities (training sessions, reading club, conferences and events) have played effective role in developing the skills mentioned below:

Circle the number that corresponds to your opinion about the statements.

[Not at all $=1 ;$ To litte extent $=2$, Just $\mathrm{OK}=$

3; To reasonable extent $=4$; To great extent $=5$ ]

11.1. Activities contents are related to Practical approach *

Mark onily one oval

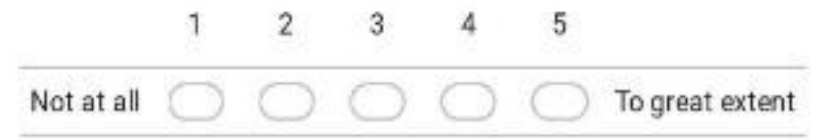

11.2. Interpersonal skills (skip if it was not available during your studies)

Mark only one oval.

$\begin{array}{lllll}1 & 2 & 3 & 4 & 5\end{array}$

Not at all $\square \square \square$ To great extent


11.3. Teamwork skills (skip if it was not available during your studies)

Mark oniy one oval.

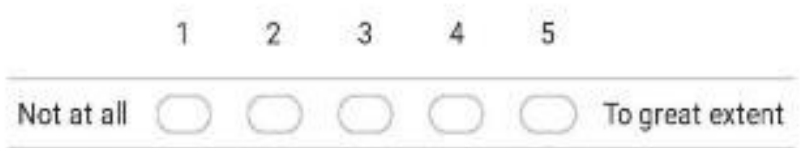

11.4. Office communication (skip if it was not available during your studies)

Mark only one oval.

$\begin{array}{llllll}1 & 2 & 3 & 4 & 5 & \\ \text { Not at all } & \square & \square & \square & \square\end{array}$

11.5. Problem solving skills (skip if it was not available during your studies)

Mark only one oval.

\begin{tabular}{llllll}
1 & 2 & 3 & 4 & 5 & \\
Not at all & $\bigcirc$ & $\bigcirc$ & \\
\hline
\end{tabular}

11.6. Database management *

Mark only one oval.

\begin{tabular}{llllll}
1 & 2 & 3 & 4 & 5 & \\
Not at all & $\bigcirc$ & $\bigcirc$ & $\bigcirc$ & $\bigcirc$ Togreat extent \\
\hline
\end{tabular}


11.7. Information technology (IT) skills *

Mark only one oval.

$\begin{array}{lllll}1 & 2 & 3 & 4 & 5\end{array}$

Not at all $\square \square \square$ Togreat extent

11.8. Online searching skills *

Mark only one oval.

$\begin{array}{lllll}1 & 2 & 3 & 4 & 5\end{array}$

Not at all $\square \square \square \square$ To great extent

11.9. Research skills *

Mark only one oval.

$\begin{array}{lllll}1 & 2 & 3 & 4 & 5\end{array}$

Not at all $\square \square \square$ To great extent

12. Do you think the following skills are important for your better employability in labor market?
Circle the number that corresponds to your opinion about the statements.

[Strongly disagree $=1$; Disagree $=2$; Just OK $=3$; Agree $=4$; Strongly Agree= 5].

12.1. Presentation skills *

Mark only one oval.

$\begin{array}{lllll}1 & 2 & 3 & 4 & 5\end{array}$

Strongly disagree $\square \square \square \bigcirc \bigcirc$ Strongly Agree


12.2. Good academic record *

Mark oniy one oval.

$\begin{array}{llllll}1 & 2 & 3 & 4 & 5 \\ \text { Strongly disagree } & \square & \square & \square & \square\end{array}$

12.3. Good interview skills *

Mark only one oval.

\begin{tabular}{lllllll} 
& 1 & 2 & 3 & 4 & 5 & \\
Strongly disagree & $\square$ & $\square$ & & & & \\
\hline
\end{tabular}

12.4. Teamwork *

Mark onily one oval.

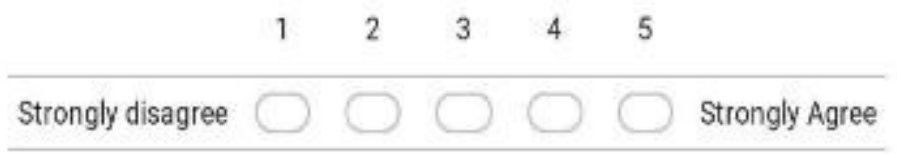

12.5. Problem solving aptitude *

Mark only one oval.

$\begin{array}{lllll}1 & 2 & 3 & 4 & 5\end{array}$

Strongly disagree $\square \square$ Strongly Agree


12.6. Good report writing skills *

Mark only one oval.

$\begin{array}{lllll}1 & 2 & 3 & 4 & 5\end{array}$

Strongly disagree

Strongly Agree

12.7. Information technology (IT) skills *

Mark only one oval.

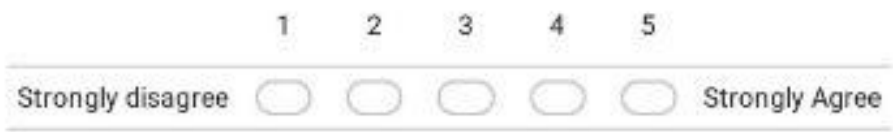

12.8. Online searching skills *

Mark onfy one oval.

$\begin{array}{lllllll} & 1 & 2 & 3 & 4 & 5 & \\ \text { Strongly disagree } & \bigcirc & \longrightarrow & \bigcirc & \bigcirc & \bigcirc & \\ \text { Strongly Agree }\end{array}$

12.9. Friendly attitude *

Mark oniy one oval.

$\begin{array}{lllllll} & 1 & 2 & 3 & 4 & 5 & \\ \text { Strongly disagree } & \square & \square & \square & \square & \square & \\ \text { Strongly Agree }\end{array}$


12.10 Learning skills *

Mark only one oval.

$\begin{array}{lllllll} & 1 & 2 & 3 & 4 & 5 & \\ \text { Strongly disagree } & \longrightarrow & & & & & \end{array}$

12.11. Time management *

Mark only one oval.

$\begin{array}{lllll}1 & 2 & 3 & 4 & 5\end{array}$

Strongly disagree $\square \square \square$ Strongly Agree

12.12. Achieving Professional goals *

Mark only one oval.

\begin{tabular}{lllllll}
1 & 2 & 3 & 4 & 5 \\
Strongly disagree & $\square$ & $\square$ & $\square$ & \\
\hline
\end{tabular}

12.13. Plan and organize independently *

Mark only one oval.

$\begin{array}{lllll}1 & 2 & 3 & 4 & 5\end{array}$

Strongly disagree $\square \bigcirc \square$ Strongly Agree




\section{Use of Library:}

13.1. How frequently did you visit your WIUT library during your studies? (Please tick one)

Mark only one oval.

$\square$ Daily
2-3 times a week
Once a week
$1-2$ times in a month
Rarely
Never

13.2. For what purpose did you visit WIUT library? (You may tick more than one)

Check all that apply.

$\square$ To complete assignments
$\square$ To prepare for examination
$\square$ For circulation (borrowing books)
$\square$ To borrow books for friends
$\square$ For updating yourself
$\square$ For recreation
$\square$ For preparing notes
$\square$ To read personal books
$\square$ For reference
$\square$ For browsing
$\square$ For Research

13.3. Which of the following services did you use in WIUT library (You may tick more than one) *

Check all that apply.

Circulation (borrowing books)

- Reference

Referencing tool sessions

WebOPAC

$\square$ Reading Club

$\square$ LRC Digital Library

Reservation of books service

Thanks for your cooperation! 